21 Linguaculture 2, 2019

\title{
C.S. LEWIS AS A CENTRAL FIGURE IN FORMULATING THE THEISTIC ARGUMENT FROM DESIRE
}

\author{
Peter S. WILLIAMS \\ Gimlekollen School of Journalism and Communication, NLA University, Norway
}

\begin{abstract}
C.S. Lewis made various theistic arguments from the existence of a desire that he called "Joy", "Romantic" longing or "Sehnsucht". This paper evaluates Lewis' contribution to this area of natural theology by situating it within an exploration of: a) the historical roots of such arguments, b) historic theological reflections upon desire, c) historic formulations of theistic arguments from desire, d) Lewis' contemporaries who made theistic arguments from desire, and e) the contemporary philosophical discussion of theistic arguments from desire. With respect to the contemporary discussion, I focus upon my own defence of a cumulative argument from desire inspired by Lewis' writings.
\end{abstract}

Keywords: Argument, Desire, Joy, Lewis, Sehnsucht

\section{Introduction}

French atheist André Comte-Sponville writes:

I would prefer . . . that God did exist, and this is one of my reasons for not believing it. An existence which corresponds at this point to our strongest desires, how can we not suspect that it has been invented to satisfy them? It's what Freud calls an illusion: a belief derived from human desires. (ComteSponville. “Atheist Spirituality.”)

C.S. Lewis was well acquainted with Sigmund Freud's critique of religion, but rejected his assertion that God must be an illusion because we 
desire him. ${ }^{1}$ Indeed, Lewis did more than any other twentieth century scholar to develop the inversion of Freud's critique known as "The argument from desire" (AFD), a family of arguments that move from an analysis of human desire to the conclusion that God exists (or that "eternal life in relationship with God" is the true human telos, goal or purpose).

Lewis sought to understand an "unsatisfied desire which is itself more desirable than any other satisfaction," a mystical experience to which he gives the technical label "Joy" (Surprised by Joy, p. 12) and which writers in the German Romantic tradition called Sehnsucht. He used the terms "Joy" and "Romantic" to name this bitter-sweet experience of feeling drawn to a transcendent and innately desirable "something more" beyond one's worldly grasp. This experience is occasioned but not satisfied by various worldly "triggers". These "triggers" are somewhat person-relative, but often have to do with beauty and/or natural grandeur (i.e. what the Romantics called "the sublime”).

Lewis produced the pre-eminent literary engagement with Sehnsucht in English, contemplating "Joy" in allegory, autobiography, apologetics, theology and sermon. He argued about "Joy" in a variety of contexts and evoked "Joy" in his fiction.

Lewis wasn't the first to explore this theme (which can be found in the Jewish scriptures). Nor was he the first to make a theistic AFD—something done by Boëthius, Pascal, Thomas Chalmers and G.K. Chesterton before him. Nor was he the only scholar of his era to do so (the AFD is mentioned by T.C. Hammond, C.E.M. Joad, Jacques Maritain and Leslie D. Weatherhead). However, it is primarily due to Lewis' wide-ranging discussion of the AFD that an increasing number of contemporary scholars have become interested in exploring, critiquing and/or defending a variety of arguments from desire (e.g. attention has been paid to the AFD by Gregory Bassham, Todd Buras, Michael Cantrell, C. Stephen Evans, Paul M. Gould, John Haldane, Robert Hoyler, Peter Kreeft, Alister McGrath, Alvin Plantinga, Joe Puckett Jr., Victor Reppert, Erik Wielenberg, etc.).

I have myself elaborated and defended the AFD as a cumulative case argument composed of a variety of sub-arguments with different logical formulations, most notably in a written debate with Gregory Bassham (see: Bassham, ed. and Williams, "In Defence of Arguments from Desire” ).

\footnotetext{
${ }^{1}$ Freud's critique can't be generalized without self-contradiction (since this would mean applying Freudian scepticism to our desire for truth) and is contradicted by innumerable counter-examples where we strongly desire things known to exist.
} 


\section{Historical Roots}

The AFD was powerfully presented and popularised by C.S. Lewis in the twentieth century, but its roots stretch back into antiquity. ${ }^{2}$ Psalm 42 (eleventh/tenth century BC) opens with the declaration that: "As the deer pants for streams of water, so my soul pants for you, my God.” The Old Testament book of Ecclesiastes (tenth-seventh century BC) can be read as an extended meditation upon this theme.

- Plato (c. 428-348 BC)

In his Symposium, Plato extolled desire for the absolute beauty of divinity:

This is the right way of approaching or being initiated into the mysteries of love, to begin with examples of beauty in this world, and using them as steps to ascend ... until ... one arrives at the supreme knowledge whose sole object is that absolute beauty, and knows at last what absolute beauty is. "This above all others ... is the region where a man's life should be spent, in the contemplation of absolute beauty. Once you have seen that, you will not value it in terms of gold or rich clothing ... What may we suppose to be the felicity of the man who sees absolute beauty in its essence ... who, instead of a beauty tainted by human flesh ... is able to apprehend divine beauty where it exists apart and alone? Do you think that it will be a poor life that a man leads who has his gaze fixed in that direction, who contemplates absolute beauty with the appropriate faculty and is in constant union with it? Do you not see that in that region alone where he sees beauty with the faculty capable of seeing it, will he be able to bring forth not mere reflected images of goodness but true goodness, because he will be in contact not with a reflection but with the truth? And having brought forth and nurtured true goodness he will have the privilege of being beloved of God, and becoming, if ever a man can, immortal himself.”

(www.ourcivilisation.com/smartboard/shop/plato/symp3.htm. n.d..)

In arguing for the superior felicity of a life orientated towards "divine beauty", Plato evinces a desire "to apprehend divine beauty" that's grounded in more earthy experiences. He also affirms that the existence of lesser beauties presupposes the existence of "absolute beauty in its essence", namely "divine beauty”. However, Plato doesn't make a connection between human desire and the existence of God per se.

\footnotetext{
${ }^{2}$ See Davis Jr., Walton, Kreeft.
} 
- Aristotle (384-322 BC)

In his Ethics, Aristotle observed that humans act to achieve an end (telos) that we desire on account of its perceived goodness. He distinguished between real and merely apparent goodness in the ends we seek (for the mere fact that we desire something doesn't guarantee that it is objectively desirable). Aristotle concludes that the good life is one directed towards the summum bonum (the highest real good for humanity).

Aristotle's term for the summum bonum of humanity is eudaimonia, which is traditionally translated as "happiness". However, eudaimonia refers to an objectively blessed state of being "rather than the feeling of happiness or joy (delectatio) which accompanies it" (McDermott, p. 315.) Many contemporary philosophers therefore prefer to translate eudaimonia as "flourishing".

While Aristotle thinks that eudaimonia is a god-like state of being (cf. Brodie), he doesn't make the connection between eudaimonia and God that one sees in the Judeo-Christian scriptures. As Christopher Shields explains, due to "unclarities and instabilities in his approach to the summum bonum", Aristotle thought that even if something like a universal form of goodness were to exist, "the universal good itself would prove utterly otiose: it would be of no practical use to any actual agent engaged in the activities of daily life ...." (Shields.) Shields observes: "Plato evidently accepts, while Aristotle plainly rejects, a single separated Form of Goodness which somehow implicates itself into our daily conduct.” (Ibid.)

Although Aristotle's God is an ultimate causal pre-condition of everything besides God, the causality in question is final (i.e. teleological) rather than efficient in nature. Aristotle's God was the Prime Mover of the cosmos, not its Creator:

Aristotle's Prime Mover only serves to account for the [universe's] everlasting motion ... Aristotle did not think it necessary to explain the existence of the universe. Being [in his view] eternal, it never came into existence, and so... it did not need an efficient cause that brought it into being.

(Adler, pp. 187-188.)

Aristotle's God isn't a specific precondition for the fulfilment of any specific human desire; hence, although desire is inherently teleological, and although Aristotle's argument for God is teleological, it isn't an AFD per se. Indeed, for Aristotle, the sort of relationship with God described in Psalm 42 couldn't factor into the human desire for eudaimonia. He thought that, as the Prime 
Mover, God had no capacity for relating to anyone or anything outside of Himself.

\section{Historic Theologial Reflections}

- Augustine of Hippo (354-430 AD)

As David Horner observes, "Augustine goes beyond the pagan thinkers . . . in arguing that happiness is ultimately found only in the enjoyment of God himself, in the beatific or blessed vision of God." (Horner. www.cslewis.org.) As Augustine states in The City of God:

[God] himself is the fountain of our happiness; he himself is the end of all of our longing. In choosing him, or rather, since we had lost him through neglect, in rechoosing him ... we strive toward him by love, so that by attaining him we might rest, happy because we are perfected by him who is our end. Thus, our good, the end which is extensively disputed among the philosophers, is nothing other than to cling to him. (Augustine qtd. in Augustine: Political Writings, p. 73.)

In his Confessions, Augustine lamented: "I looked for pleasure, beauty, and truth not in [God] but in myself and his other creatures, and the search led me instead to pain, confusion, and error." (Confessions, pp. 22-3.) Augustine came to believe that the true object of his desire was God, and to exclaim: "Late have I loved you, beauty so old and so new: late have I loved you!" (Confessions, p. 201.) With the benefit of hindsight, Augustine concluded: "You have made us for yourself, Lord; and our heart is restless until it rests in you." (Confessions, p. 3.)

- Thomas Aquinas (1225-1274)

Aristotle's teleological approach to eudaimonia was given a Christian interpretation by Thomas Aquinas, who applies the concept of the summum bonum to John 17:3: "Now this is eternal life: that they know you, the only true God, and Jesus Christ, whom you have sent." (NIV.) Aquinas argued that eudaimonia is found in a reciprocal relationship with God within the community of people who love God because he first loved them. Love of God, in Christ, is our summum bonum. This relationship begins in this life, and flourishes in the next. This telos is an unlimited and normative real good because it involves knowing and loving God, neighbour and cosmos for eternity. Aquinas wrote:

The natural desire to know cannot be stilled until we know the first cause, not in any sort of way but in its essence. Now, the first cause is God. Therefore, the end 
of the rational creature is the vision of the divine essence. (Aquinas. Compendium Theologiae 104, qtd. in Copleston.)

- Bonaventure Fidanza (1221-1274)

Bonaventure Giovanni Fidanza held that humans have an implicit knowledge of God which can be made explicit through reflection. He reasoned that since every human naturally desires eudaimonia, and since this requires possession of the summum bonum, which he identified with God, it follows that every human naturally desires God (whether they know this explicitly or not).

Aquinas responded to Bonaventure that:

To know that someone is coming is not to know that Peter is coming, although the person coming is in fact Peter. And many have thought that man's perfect good, which is happiness, consists in riches; others that it consists in pleasure; others that it consists in some other thing. (Aquinas. Summa Theologica, qtd. in Copleston, p. 108.)

However, as F.C. Copleston comments:

Aquinas . . . admits that man's natural desire for happiness implies a kind of implicit knowledge of God, in the sense that when we once know that God exists and that possession of Him constitutes human happiness we can interpret the desire for happiness as the desire for God. (pp. 107-108.)

The point of contention between Bonaventure and Aquinas is whether this implicit knowledge of God means "that anyone has a natural innate knowledge of the truth of the proposition that God exists.” (Copleston, p. 108.)

Bonaventure's argument shows that if God exists then people have a natural desire for God. Of course, Christian theology also says that people are sinful, and that this shows itself in a demand for autonomy from God that fights against our natural desire for God. Human sinfulness, together with the fact that Joy is occasioned by earthly triggers that may be mistaken for that which we truly desire, provide non-ad-hoc explanations for the fact that "many have thought that man's perfect good . . . consists in riches . . . in pleasure [or] in some other thing.” (Aquinas, Summa Theologica, qtd. in Copleston.)

Aquinas denied that an innate desire for God implies an innate propositional knowledge of God. However, Aquinas' counter-example of knowing that someone is coming (which is knowing something) but not thereby knowing who is coming (failing to know everything about the coming someone), doesn't carry the force he intends. After all, an argument for God needn't tell us everything about God! If I know that someone is coming (perhaps because I can hear footsteps approaching), I may be able to reason my way to some 
conclusions about who is coming. That is, even if desire for a thing doesn't presuppose propositional knowledge of that thing, it may still be the case that desire for a thing is a sufficient basis for coming to know some propositions about the object of one's desire. For example, if I know that someone is coming because I can hear their footsteps approaching, I may well be able to conclude that this someone can walk, and can do so at a certain speed, while wearing high heels. Similarly, from a desire for God we may be able to conclude several facts about the object of our desire.

Bonaventure argued for an innate knowledge of God that has not been given explicit propositional form. What we are envisaging here is the sort of knowledge whereby someone who 'found God' might say: "Here at last is what I was looking for all along. In a sense, I knew what I wanted, but only now have I found it and realised in the finding that what I wanted was God.” The search for the object of this desire is a search to discover that which answers to the "description" given by our desire, that which answers the shape of our spiritual hunger. This search can progress through experience from the inchoate, to the vague, to the less vague, and so on; but it may also progress through philosophical meditation.

\section{Historic Formulations of the AFD}

- Anicius Manlius Severinus Boëthius (c. 475-526 AD)

In The Consolation of Philosophy, Boëthius wrote: "Now a man must be lacking something if he misses it, mustn't he?” (p. 83.) What Boëthius thinks humans lack is perfect happiness. First, in a process of argument by elimination, Boëthius rejects various goals commonly thought to offer happiness (money, fame, high office, bodily pleasure and physical beauty). Then he argues that "if you do away with perfection, it is impossible to imagine how that which is held to be imperfect could exist" and deduces that since "there is a certain imperfect happiness in perishable good . . . there can be no doubt that a true and perfect happiness exists.” (The Consolation of Philosophy, p. 99.)

Boëthius builds upon this axiological deduction by arguing that "God and happiness are one and the same," that "the good itself and happiness are identical," and that it should consequently be thought "infinitely valuable" to be able "to see God, who is the Good." (Ibid., p.104.) In short, according to Boëthius:

Since it is through the possession of happiness that people become happy, and since happiness is in fact divinity, it is clear that it is through the possession of divinity that they become happy. But by the same logic as men become... wise through the possession of wisdom, so those who possess divinity necessarily 
become divine. Each happy individual is therefore divine. While only God is so by nature, as many as you like may become so by participation.

(The Consolation of Philosophy, p. 102.)

Hence Boëthius provides our first example of a theistic AFD.

- Blaise Pascal (1623-1662)

Pascal observed that humans contain an "infinite abyss [that] can be filled only with an infinite, immutable object, that is to say, only by God Himself.” (52) ${ }^{3} \mathrm{He}$ wrote that: "From the time we have forsaken him, it is a curious thing that nothing in nature has been capable of taking his place.” (Pascal, p. 52) This argument appears to be abductive in form, offering the repeated experience that finite objects fail to fill the abyss in the human heart as evidence for the conclusion that the human heart desires an infinite, and thus transcendent object:

Man tries unsuccessfully to fill this void with everything that surrounds him, seeking in absent things the help he cannot find in those that are present, but all are incapable of it. This infinite abyss can be filled only with an infinite, immutable object, that is to say, God himself. He alone is our true good.

(Pascal, p. 52.)

\section{- Thomas Chalmers (1780-1847)}

Scottish theologian Thomas Chalmers observed that:

For every desire or every faculty, whether in man or in the inferior animals, there seems a counterpart object in external nature . . . there exists a something without that is altogether suited to it, and which seems to be expressly provided for its gratification. There is light for the eye; there is air for the lungs; there is food for the ever-recurring appetite of hunger; there is water for the appetite of thirst . . . in a word, there seems not one affection in the living creature, which is not met by a counterpart ... (Chalmers qtd. in Hammond, p. 56.)

Chalmers went on to note: "There is in man a restlessness of ambition; an interminable longing after nobler and higher things . . . a dissatisfaction with the present, which never is appeased by all that the world has to offer." (Chalmers qtd. in Hammond, p. 56.) The conjunction of these premises suggests the inference that there probably exists a transcendent satisfaction for man's transcendent longing.

\footnotetext{
${ }^{3}$ Pascal did not write that "There is a God-shaped vacuum in the heart of every man".
} 
- G. K. Chesterton (1874-1936)

Catholic writer G. K. Chesterton makes a couple of brief prima facie observations about God and desire in his book The Everlasting Man (1925):

absence does not mean non-existence; and a man drinking a toast of absent friends does not mean that from his life all friendship is absent. It is a void but it is not a negation; it is something as positive as an empty chair.

(The Everlasting Man, p. 106)

Again:

there is in a very real sense the presence of the absence of God. We feel it in the unfathomable sadness of pagan poetry ... (p. 107)

Brief as they are, these remarks may have had an impact upon C.S. Lewis, since we know he read The Everlasting Man (cf. Como, p. 124).

Thus Lewis' predecessors formulated deductive, abductive, inferential and prima facie versions of the AFD.

\section{Lewis' Contemporaries Who Argued from Desire}

Several contemporaries of Lewis offered theistic arguments from desire:

- T.C. Hammond (1877-1961)

Irish Anglican cleric and apologist Thomas Chatterton Hammond offered an AFD in his 1943 text Reasoning Faith, albeit by quoting heavily from Thomas Chalmers.

- C.E.M. Joad (1891-1953)

In 1946 British philosopher C.E.M. Joad offered a prima facie AFD when he mused: "aesthetic emotion is at once the most satisfying and the most unsatisfying of all the emotions known to us; satisfying because of what it gives, unsatisfying because it gives so briefly, and, in the act of giving hints at greater gifts withheld”. (Guide to Philosophy, p. 354.)

In 1952 Joad (whose conversion to Christianity had been influenced by Lewis) framed the AFD as a reductio:

if the objects that satisfy religious need did not exist, it is hard to see how the existence of the need itself is to be explained. Granted [the Freudian theory] 
that man has made the belief in the objects affirmed by religion because he needs it, he did not create the circumstances in which he needs the belief, the circumstances which obliged him to invent it. Hence, the demand for a religious faith by human beings must be based on the same real nature of things as that which produced the human beings who made the demand. It is hard to credit in practice and it leads to self-contradiction in theory to suppose that nature has constituted man in such a way that he can only survive and prosper if he holds a belief in something which is not. (The Recovery of Belief , p. 91.)

\section{- Jacques Maritain (1882-1973)}

In Approaches to God (1954), Neo-Thomist philosopher Jacques Maritain articulated a deductive AFD:

Because this desire which asks for what is impossible to nature is a desire of nature in its profoundest depths, it cannot issue in an absolute impossibility ... . it asks for what is impossible for nature. But it is necessary that by some means (which is not nature) it be able to be satisfied, since it necessarily emanates from nature. (Approaches to God, p. 112.)

\section{- Leslie D. Weatherhead (1893-1976)}

In 1955 Methodist theologian Leslie D. Weatherhead responded to Freud's case against theism with a reductio AFD:

If I assert the fact of physical hunger-a desire for food-and deduce that, in a rational universe, that fact points to the fact of food, does my concept of food mean that food is necessarily a figment of my imagination and cannot exist? Assuredly not. If, then, I assert the fact of spiritual hunger - a desire for a fatherly God - and dream that there is a Satisfaction for it . . . does my dream deny the reality? As assuredly not . . . In a rational universe, rather the reverse.

(Weatherhead, p. 404.)

\section{The Contemporary Discussion}

Sehnsucht continues to haunt humanity in the twenty-first century, as noted by sociologist Charles Taylor in his monumental A Secular Age (Harvard University Press, 2007), which is framed by the issue of our desire for spiritual transcendence and/or self-transcendence, including the experience that Lewis called "Joy". 4

Although the AFD was advanced before Lewis, and although Lewis had contemporaries who offered several formulations of the argument, it's apparent

\footnotetext{
${ }^{4}$ See also: Anonymous. What Is Culture For?, 25 \& 40.
} 
that it is primarily Lewis' sustained and rhetorically varied engagement with the AFD that has inspired the contemporary discussion thereof.

Lewis didn't restrict his discussion of desire to the experience he called "Joy", counting "the irrepressible thirst for immortality" among the contents of "natural desire" ("The Sagas and modern life" (1937) in Image and Imagination, p. 318). Contemporary writers likewise describe $a$ range of existentially relevant innate desires. For example, Taylor notes "our aspiration to separate ourselves from evil and chaos . ..” (Taylor, p. 711); Anthony O'Hear speaks of "the perfection we long for in some other world." (O’Hear, p. 144), while Roger Scruton notes "those ancient and ineradicable yearnings for something else-for a homecoming to our true community" (Scruton, p. 27.).

Contemporary philosophers and apologists have a tendency to assume there is one proper or best way to formulate the AFD. For example, according to Alister McGrath, "While some have misunderstood Lewis's approach as a deductive argument for the existence of God, it is clearly an abductive or inferential argument...” (The Intellectual World of C.S. Lewis, p. 105.) It seems to me that McGrath reads Lewis through the obscuring lens of his own preferred apologetic method, rather than recognizing that Lewis presented the AFD in various different logical forms (including deductive).

Likewise, Alvin Plantinga works the AFD into his preferred approach to religious epistemology, arguing for the properly basic status of theistic belief evoked by desire:

Perhaps this restlessness without God leads to belief in God; and perhaps God has designed us in this way to impel us to try to get in touch with him... the process leading to the formation of the beliefs in question are directed to the truth: the relevant module of the design plan has as its purpose the production of true belief, even if it goes by way of perception of beauty or wish-fulfillment.

(Plantinga, p. 307.)

Building upon Lewis and Plantinga, Todd Buras and Michael Cantrell have recently argued that: 1) "God" is a precondition of humans obtaining "complete happiness", that 2) "complete happiness" is "a seemingly non-defective desire" and that 3) "a seemingly non-defective desire is a prima facie indication of the possibility of its object” (Buras and Cantrell). It follows that 4) God's existence is prima facie possible, a conclusion that in turn supports the key premise of the modal ontological argument developed by Plantinga (i.e. the possibility of God's existence). ${ }^{5}$

\footnotetext{
${ }^{5}$ See: Williams, A Faithful Guide to Philosophy.
} 


\section{A Cumulative AFD}

Inspired by Lewis, I have advanced a cumulative AFD composed of subarguments arraigned in different logical forms.

\section{Prima Facie AFD}

Samuel Alexander's Gifford Lectures on Space, Time and Deity (1916-1918) introduced C.S. Lewis to the distinction between "Enjoyment" and "Contemplation," a distinction Lewis would later illustrate in terms of looking at or looking along a beam of light. To take the phenomenology of "Joy" at face value means looking along it towards an innately desirable "transcendent other." Now, as Lewis points out: "As soon as you have grasped this simple distinction [between looking at and looking along], it raises a question. You get one experience of a thing when you look along it and another when you look at it. Which is the 'true' or 'valid' experience"? (Lewis. "Meditation in a Toolshed." First and Second Things, p. 51.) Lewis observes:

It has . . . come to be taken for granted that the external account of a thing somehow refutes or "debunks" the account given from inside. "All these moral ideas which look so transcendental and beautiful from inside," says the wiseacre, "are really only a mass of biological instincts and inherited taboos." And no one plays the game the other way round by replying, "If you will only step inside, the things that look to you like instincts and taboos will suddenly reveal their real and transcendental nature" (

("Meditation in a Toolshed." First and Second Things, p. 52).

Lewis argues that this reductive impulse must be resisted on at least some occasions because its generalization is incoherent: "you can step outside one experience only by stepping inside another. Therefore, if all inside experiences are misleading, we are always misled" ( "Meditation in a Toolshed." First and Second Things, p. 54). Lewis concludes "we must take each case on its merits." (Ibid.).

Moreover, Lewis' example of discovering that "the inside vision of the savage's dance to Nyonga may be found deceptive because we find reason to believe that crops and babies are not really affected by it" (Lewis, "Meditation in a Toolshed." First and Second Things, p. 52) illustrates the presumption of innocence conferred in the absence of sufficient reason for doubt upon enjoyed (i.e. looked along) experiences.

Contemporary epistemology is well disposed to playing the game "the other way round." For example, consider the "reformed epistemology" of Alvin Plantinga, who argues for the properly basic status of theistic belief evoked by desire (Plantinga, p. 307). 
To further motivate taking "Joy" at face value, I appeal to Richard Swinburne's epistemic principle "that we ought to believe that things are as they seem to be (in the epistemic sense) unless and until we have evidence that we are mistaken" (Swinburne, p. 115). This basic principle of rationality (and others like it) puts the burden of proof upon the shoulders of the sceptic who claims that, despite appearances, to look along a Joy is to experience a delusion rather than the insight into the nature of reality it seems to be from the inside.

\section{Abductive AFD}

Alister McGrath notes that "Lewis's reflections on desire focus on two themes... a general sense of longing for something . . . and a Christian affirmation that God alone is the heart's true desire ...” (The Intellectual World of C.S. Lewis, p. 106.) These themes form the two prongs of an abductive argument for the Judeo-Christian explanation of "Joy":

Lewis saw this line of thought as demonstrating the correlation of faith with experience, exploring the "empirical adequacy" of the Christian way of seeing reality with what we experience within ourselves ... Christianity ... tells us that this sense of longing for God is exactly what we should expect, since we are created to relate to God. It fits in with a Christian way of thinking, thus providing indirect confirmation of its reliability. (McGrath, Mere Apologetics, pp. 110-111.)

Victor Reppert likewise formulates the AFD as an abductive argument:

On Christian theism God's intention in creating humans is to fit them for eternity in God's presence. As such, it stands to reason that we should find ourselves dissatisfied with worldly satisfactions. Let's put the likelihood that we should long for the infinite given theism at 0.9 . . I wouldn't say that such desires couldn't possibly arise in an atheistic world . . . But how likely would they arise in such a world? So long as the answer is "less likely than in a theistic world," the presence of these desires confirms theism. Let's say that, if we don't know whether theism is true or not, the likelihood that these desires should arise is 0.7. Plugging these values into Bayes" theorem, we go from 0.5 likelihood that theism is true to a 0.643 likelihood that theism is true. Thus ... the argument from desire confirms theism. (The Bayesian Argument from Desire)

Against the abductive AFD, Erik Wielenberg tries to explain away "Joy" in terms of naturalistic evolutionary psychology (NEP). I have offered a rebuttal of Wielenberg's NEP hypothesis (see: Bassham ed.), which only engages with "two features of Joy-the restlessness it induces and the nebulousness of its object," (Wielenberg, qtd. in Bassham ed.) and thereby lacks explanatory scope. Wielenberg suggests the former feature "might" be advantageous if Joy arose: "Early humans favored with a chronic, ill-defined restlessness of heart 
might have outcompeted other humans who were naturally more sedentary and complacent." (Alternatively, we might think that early humans afflicted with "a chronic, ill-defined restlessness of heart" would be out-competed by humans free from such existential ennui!) Again, Wielenberg suggests the somewhat nebulous nature of Joy "might” be an advantageous if Joy arose: “Joy's . . lack of a clear intentional object, might have led early humans down Lewisian 'false paths,' such as the pursuit of sex, power, and adventure, that did have direct fitness advantages" (Bassham summarizing Wielenberg, in Bassham ed., pp. 116-117.) Wielenberg's use of "might” doesn't inspire confidence in either case, indicating that his hypothesis has a low degree of explanatory power.

Finally, Wielenberg offers no explanation for the appearance of "Joy" in our gene-pool, only for its natural selection should it appear. As Reppert argues:

natural desires that are unfulfillable on earth is precisely what you should expect.... from the point of view of theism. I seriously doubt that we can do this from the point of view of naturalism, even if a half-way-decent-looking evolutionary explanation of how such desires could arise were forthcoming ...

(The Bayesian Argument from Desire)

\section{Inductive AFD}

In Mere Christianity Lewis frames the AFD inferentially:

Creatures are not born with desires unless satisfaction for those desires exists. A baby feels hunger: well, there is such a thing as food. A duckling wants to swim: well, there is such a thing as water ... If I find in myself a desire which no experience in this world can satisfy, the most probable explanation is that I was made for another world. (Mere Christianity, p. 113.)

In other words, we can present the AFD with Trent Dougherty as "a defeasible inference [wherein] the premises could be true and the conclusion yet false, but they bear prima facie support for the conclusion" (Dougherty. "Argument from Desire.” Prosblogion):

1) Humans have by nature a desire for the transcendent

2) Most natural desires are such that there exists some object capable of satisfying them

3) There is probably something transcendent

Explicit reference to heaven and/or God can be substituted for Dougherty's "transcendent". 


\section{Aristotelian AFD}

In the preface to the third edition of The Pilgrim's Regress, Lewis offered a deductive AFD:

if a man diligently followed this desire, pursuing the false objects until their falsity appeared and then resolutely abandoning them, he must come at last to the clear knowledge that the human soul was made to enjoy some object that is never fully given ... in our present mode of subjective and spatio-temporal experience. This Desire was, in the soul, as the Siege Perilous in Arthur's castle-the chair in which only one could sit. And if nature makes nothing in vain, the One who can sit in this chair must exist. (Pilgrim's Regress, p. 15, my italics.)

Here Lewis assumes Aristotle's dictum that "nature makes nothing in vain" (Aristotle, The Generation of Animals, qtd. in Brodie):

1) Nature makes nothing in vain.

2) Humans have a natural desire, Joy, that would be vain unless some object that is never fully given in our present mode of existence is obtainable by humans in some future mode of existence.

3) Therefore, the object of Joy must exist and be obtainable in some future mode of human existence.

One can set to one side the universality of Aristotle's dictum whilst still giving a deductive argument based upon a restricted application of Aristotle's dictum to innate human desires:

1) Nature makes no type of innate human desire in vain.

2) Humans have innate desires that would vain if God doesn't exist.

3) Therefore, God exists.

Inductive Aristotelian arguments from desire can be mounted upon the premises that "most types of things in nature are not made in vain" or that "the majority of innate human desires are not made in vain".

Following Mariska Leunissen's reading of Aristotle in Explanation and Teleology in Aristotle's Science of Nature (2012), we could interpret Aristotle's dictum as a heuristic principle. A principle such as "We should assume that no [type of] natural thing exists in vain until and unless we are shown otherwise" could serve as a premise in a deductive heuristic AFD:

1) Humans have natural desires that would be in vain if God didn't exist.

2) We should assume that no [type of] natural thing exists in vain until and unless we are shown otherwise. 
3) Therefore (until and unless we are shown that the relevant natural desires exist in vain) we should assume that God exists.

\section{Reductio AFD}

In The Case for Christianity (1942), which became the first section of Mere Christianity (1952), Lewis framed the AFD as a reductio:

If I find in myself a desire which no experience in this world can satisfy, the most probable explanation is that I was made for another world. If none of my earthly pleasures satisfy it, that does not prove that the universe is a fraud. Probably earthly pleasures were never meant to satisfy it, but only to arouse it, to suggest the real thing. (Mere Christianity, p. 113, my italics.)

Following Lewis, I have made several reductio arguments from existentially relevant human desires and the denial of the existential claim that human life is "absurd". For example:

1) Given an instantiated kind $K$ possessing innate existential desires, the existence of $\mathrm{K}$ would be absurd to the extent that it is impossible for any member of $\mathrm{K}$ to have those existential desires satisfied

2) Humans are an instantiated kind $K$ with innate existential desires that are [probably] impossible to satisfy unless God exists

3) Therefore, unless God exists, the existence of $\mathrm{K}$ is [probably] absurd (at least to a substantial extent)

4) However, the existence of $\mathrm{K}$ is [probably] not absurd (at least, not to any substantial extent)

5) Therefore, God [probably] exists

I contend that premise 4 is a properly basic belief.

\section{Conclusion}

C.S. Lewis produced the twentieth century's principal thematic and argumentative engagement with "Joy". Many wrote about "Joy" before Lewis. Poets described the experience and theologians situated the experience within their philosophical anthropology. Starting with Boëthius, Christian thinkers including Pascal, Chalmers and Chesterton began to formulate various theistic arguments from desire. However, Lewis surpassed his predecessors, and contemporary advocates of the AFD (i.e. Hammond, Joad, Maritain and Weatherhead), by considering a plurality of innate desires (whilst focusing on "Joy") and by using a plurality of argumentative forms. Moreover, as far as I can 
tell, Lewis was the first to frame the AFD as a reductio. Hence Lewis deserves to be recognised as a central figure in the history of the theistic argument from desire, a figure who has inspired a growing engagement with the argument in contemporary philosophy and apologetics.

\section{Works Cited}

Adler, Mortimer J. Aristotle For Everybody. New York: Touchstone, 1978. Print.

Anonymous. What Is Culture For? London: The School of Life, 2018. Print.

Aquinas, Thomas. Compendium Theologiae, 104, qtd. in F.C. Copleston, Aquinas.London: Pelican Books, 1957. Print.

---. Summa Theologica, qtd. in F.C. Copleston. Aquinas. London: Pelican Books, 1957. Print.

Augustine. Confessions. Oxford: Oxford Paperbacks, 1998. Print.

---. City of God, X.3, qtd. in Augustine: Political Writings. Trans. Ernest L. Fortinand Douglas Kries. Indianapolis: Hackett, 1994. Print.

Bassham, Gregory, ed. C.S. Lewis’ Apologetics: Pro and Con. London: Rodolpi-Brill, 2015. Print.

Boethius. V.E. Watts, trans. The Consolation of Philosophy. London: Penguin, 1969. Print.

---. The Consolation of Philosophy. Book III. http://christweedt.com/BoethiusConsolation3.pdf. christwwdt.com, n.d. Web. 7 Feb. 2019.

Buras,Todd and Michael Cantrell. "C.S. Lewis's Argument from Nostalgia: A New Argument from Desire.” Ed. Jerry L. Walls and Trent Dougherty. Two Dozen (Or so) Arguments For God. Oxford: Oxford University Press, 356-321. Print.

Brodie, Sarah. "Aristotle’s Elusive Summum Bonum” .https://lucian.uchicago.edu/blogs/objects/files/2014/05/Broadie.pdf. Philosophy, Princeton University, n.d. Web 7 Feb. 2019.

Chesterton, G.K. The Everlasting Man. London: Hodder \& Stoughton, 1927. Print.

Como, James. C.S. Lewis: A Very Short Introduction. Oxford: Oxford University Press, 2019. Print.

Comte-Sponville, André. “Atheist Spirituality.” http://atheistspirituality.net/from-andrecomte-sponville/. Atheist Spirituality, n.d. Web. 7 Feb. 2019.

Copleston, F.C. Aquinas. London: Pelican Books, 1957. Print.

Davis Jr., Craig. Dating the Old Testament. London: Craig Davis, 2007. Print.

Dougherty, Trent. "Argument from Desire.” http://prosblogion.ektopos.com/archives/2005/11/argument_from_d.html. Web.

Hammond, T.C. Reasoning Faith: An Introduction to Christian Apologetics. London: VP, 1943. Print.

Horner, David. "The Pursuit of Happiness: C.S. Lewis's Eudaimonistic Understanding of Ethics.” www.cslewis.org/journal/the-pursuit-of-happiness-c-s-lewis'seudaimonistic-understanding-of-ethics/view-all/\#_ftnref10. C.S. Lewis Foundation: In Pursuit of Truth: A Journal of Christian Scholarship. 21 April, 2009. Web. 7 Feb. 2019.

Joad, C.E.M. The Recovery of Belief. London: Faber, 1952. Print. 
---. Guide to Philosophy. London: Victor Gallancz, 1946. Print.

Kreeft, Peter. Three Philosophies of Life. San Francisco: Ignatius, 1990. Print.

Leunissen, Mariska. Explanation and Teleology in Aristotle's Science of Nature. Chicago: University of Chicago Press, 2012. Print.

Lewis, Clive Staples. “The Sagas and modern life.” (1937) Image and Imagination. Ed.

Walter Hooper. Cambridge: Cambridge University Press, 2013. 315-320. Print.

---. Surprised by Joy. London: Fount, 1998. Print.

---. Mere Christianity. London: Fount, 1997. Print.

---. Pilgrim's Regress. London: Fount, 1977. Print.

---. "Meditation in a Toolshed." First and Second Things. London: Fount, 1985. Print.

Maritain, Jacques. Approaches to God. New York: Harper \& Brothers, 1954. Print.

McGrath, Alister. The Intellectual World of C.S. Lewis. Oxford: Wiley-Blackwell, 2014. Print.

---. Mere Apologetics. Grand Rapids, Michigan: Baker, 2012. Print.

McDermott, Timothy. Aquinas-Selected Philosophical Writings. Oxford: Oxford University Press, 1993. Print.

O'Hear, Anthony. Philosophy in the New Century. London: Continuum, 2001. Print. Pascal, Blaise. Honor Levi, trans., Pensées and other writings. Oxford: Oxford University Press, 1995. Print.

Plantinga, Alvin. Warranted Christian Belief. Oxford: Oxford University Press, 2000 Print.

Plato, Symposium. www.ourcivilisation.com/smartboard/shop/plato/symp3.htm.ourcivili zation.com, n.d. Web. 7 Feb. 2019.

Reppert, Victor. "The Bayesian Argument from Desire”. http://dangerousidea.blogspot.com/2006/09/bayesian-argument-from-desire.

html\#comments. Dangerous Idea, 2006. Re-dated Post: 14 Sept. 2009. Web. 7 Feb. 2019.

Scruton, Roger. An Intelligent Person's Guide to Modern Culture. London: Duckworth,1999. Print.

Shields, Christopher. "The Summum Bonum in Aristotle’s Ethics: Fractured Goodness.” http://cjishields.com/summum-bonum-fractured.pdf. cjshields.com, n.d. Web. 7 Feb. 2019.

Swinburne, Richard. Is There A God? rev. ed. Oxford: Oxford University Press, 2010. Print.

Taylor, Charles. A Secular Age. Cambridge: Harvard University Press, 2007. Print.

Walton, John. "Who Wrote Ecclesiastes and What Does It Mean?" https://zondervanacademic.com/blog/who-wrote-ecclesiastes-and-what-does-itmean/. Zondervan Academic. 21 Oct, 2017. Web. 7 Feb. 2019.

Weatherhead, Leslie D. Psychology, Religion and Healing. London: Hodder \& Stoughton, 1955. Print.

Williams, Peter S. A Faithful Guide to Philosophy: A Christian Introduction to the Love of Wisdom. Eugene, Oregon: Wipf \& Stock, 2019. Print.

---. C.S. Lewis vs. the New Atheists. London: Paternoster, 2013. Print.

---. "Debate: Does God Exist? Peter S. Williams vs. Einar Bohn at the Norwegian University of Science and Technology in Trondheim.” 
http://peterswilliams.podbean.com/mf/feed/e5dvj8/Trondheim_2018_Debate.m p3arguments-from- desire/. 2018. Web. 7 Feb. 2019.

---. “In Defence of Arguments from Desire.” www.peterswilliams.com/2016/11/02/indefence-of-arguments- from-desire/. 02 Feb. 2016. Web. 7 Feb. 2019.

---. The Case for God. Crowborough: Monarch, 1999. Print.

Peter S. Williams (MA, MPhil) is a UK based philosopher and apologist and an Assistant Professor in Communication and Worldviews at Gimlekollen School of Journalism and Communication, NLA University College, Norway. His publications include: Getting at Jesus: A Comprehensive Critique of Neo-Atheist Nonsense about the Jesus of History (Wipf \& Stock, 2019); A Faithful Guide to Philosophy: A Christian Introduction to the Love of Wisdom, reprint edition (Wipf \& Stock, 2019); C.S. Lewis vs. the New Atheists (Paternoster, 2013); Understanding Jesus: Five Ways to Spiritual Enlightenment (Paternoster, 2011) and A Sceptic's Guide to Atheism (Paternoster, 2009). He is co-editor of C.S. Lewis at Poets' Corner (Cascade, 2016) and a contributor to Craig Blomberg et al, Resurrection: Faith or Fact? A Scholars' Debate Between a Skeptic and a Christian (Pitchstone, 2019) and C.S. Lewis's Christian Apologetics: Pro and Con (Brill/Rodopi, 2015). Peter is currently writing a response to neo-atheist Richard Dawkins' latest book, Outgrowing God (Bantam, 2019). See www.peterswilliams.com.

Email: peterswilliams@googlemail.com 
